\title{
Germination behavior of the extremely rare Hladnikia pastinacifolia Rchb. (Apiaceae) - a Pleistocene in situ survivor
}

\author{
Nina Šajna ${ }^{1 *}$, Mirjana Šipek ${ }^{1}$, Jelka Šuštar - Vozlič̌2 $\check{c}^{2}$ Mitja Kaligarič ${ }^{1}$ \\ ${ }^{1}$ University of Maribor, Faculty of Natural Sciences and Mathematics, Koroška c. 160, SI-2000 Maribor \\ ${ }^{2}$ Agricultural Institute of Slovenia, Hacquetova ulica 17, SI-1000 Ljubljana
}

\begin{abstract}
The present-day diversity of European flora in temperate mountain ranges was mainly formed by the negative effects of Pleistocene glaciation, which caused extinctions, restricted survival in situ, and subsequent re-colonization. Only rarely can we find species that have retained the molecular information of in situ survival. One such example is the extremely rare H. pastinacifolia Rchb., a monotypic genus and a narrow endemic of a mountain plateau south-east of the Julian Alps (Slovenia). We investigated the germination behavior and dispersal indications, which are often closely related to rarity and persistence and thus valuable for species conservation. Additionally, results about $H$. pastinacifolia help us to understand better what kind of species survived glaciations in Europe in situ. Our results show that these seeds have an underdeveloped embryo and require an ecologically relevant moist chilling period of about 100 days. The temperature sequence of the colder period that $\mathrm{H}$. pastinacifolia seeds received in nature was $20 / 15^{\circ} \mathrm{C}$ (52 days), $10 / 5^{\circ} \mathrm{C}$ (40 days), $5 / 0{ }^{\circ} \mathrm{C}(65$ days), $10 / 0{ }^{\circ} \mathrm{C}$ ( 45 days), $15 / 5^{\circ} \mathrm{C}$ ( 21 days). The germination rate was high, significantly increased by scarification, and therefore prevented long-term seed bank establishment. We found cryptic seed differences expressed by two types of dormancy, each related to the order of the umbel: simple and complex morphophysiological dormancy for the lateral and the main umbel, respectively. Seed dispersal was very much influenced by precipitation in autumn. The germination and dispersal characteristics could explain the rarity and at the same time the persistence of H. pastinacifolia.
\end{abstract}

Keywords: Apioideae, seed dormancy, embryo: seed ratio, temperate region, endemic, Pleistocene survivor, persistences

\section{Introduction}

The Trnovski gozd Karst Plateau, a mountainous area in western Slovenia with elevations up to $1500 \mathrm{~m}$, has an important biogeographic position, representing a meeting zone between the southern sub-Mediterranean and Dinaric biomes, and the northern Alpine one. It represents an orographic barrier characterized by precipitation that is unusually high compared to other, nearby, regions of Slovenia, reaching above $3000 \mathrm{~mm}$ yearly in 120 precipitation days, mainly as snow, which can last up to 6 months (Melik 1960). The precipitation peak falls in October and November; however, because of high oscillations in October, in some years precipitation is absent (Pristov 1997). Because of the Jurassic and Cretaceous limestone bedrock dominating the plateau (Orehek and Ogorelec 1979), it is strongly karstified, without sur- face water bodies (Grom 1969, Kranjc 2006). Biogeographic location and the specific environmental factors contribute to extremely high plant species diversity with many endemics, even though much of the plateau is covered by dense forest stands, except for steep overhangs on the southern and northern edges, representing continuously open vegetation.

During the Pleistocene, a local glacier was present in this region (Perko 2001). However, the highest peaks remained un-glaciated, constituting a small nunatak. One species that could be connected to survival in situ is the endemic monotypic Hladnikia pastinacifolia Rchb. with a distinct taxonomic position within the Apiaceae Lindl. (Umbelliferae Juss.) family (Šajna et al. 2012) - a species found only on Trnovski gozd and nowhere else in the world. The species was discovered

*Corresponding author e-mail: nina.sajna@um.si 
as late as 1819 and was from the very beginning regarded as an ancient paleo-endemic and Tertiary relict species (Mayer 1960, Pawlowski 1970). This has also been confirmed by recent molecular studies showing that all known populations of $H$. pastinacifolia are genetically depauperated as a consequence of survival during Pleistocene glaciation in situ on Trnovski gozd Karst Plateau (Šajna et al. 2012).

In situ survival theories have rarely been used to explain the phylogeographic patterns in temperate mountain ranges, despite numerous phylogeographic studies, since rare species which lack the potential for rapid range expansion and re-colonization are the ones most likely to retain the molecular information of in situ survival (Westergaard et al. 2011). In cases in which, because of re-colonization, in situ survivors and conspecific populations from nonglaciated peripheral refugia have met, the genetic information was lost by interbreeding. Besides molecular information, survival in situ should also be recognizable from the current distribution pattern and species ecology (Schneeweiss and Schönswetter 2011). The distribution area of $H$. pastinacifolia is extremely narrow (less than 4 $\mathrm{km}^{2}$; Čušin 2004), fragmented and lying in the near proximity of an area believed to have remained non-glaciated (Šajna et al. 2012). The species' occurrence is restricted to the southern and northern, non-forested edges of the plateau and the upper belt of their steep overhangs. Hladnikia pastinacifolia is considered an in situ survivor, not only because of its narrow range size, distribution pattern and genetic diversity, but also on account of its endemism, temporal persistence, rarity and taxonomic distinctness (Šajna et al. 2012).

However, its rarity is somewhat surprising, since this saxicolous species is not a habitat specialist occupying a narrow ecological niche. It can be found growing in various habitats, like stony grassland, rock crevices and screes (Šajna et al. 2012). Most habitats are sloped; in the Northern distribution margin, both populations are restricted to vertical rock outcrops. In general, habitats of $H$. pastinacifolia are characterized by high environmental stress and a medium disturbance regime, preventing shading and rapid succession.

Lack of specific habitat preference also explains why $H$. pastinacifolia can be found in very variable plant communities (Wraber 1990), which have been well described phytosociologically (Martinčič 1961, Poldini 1978, Kaligarič 1997, Kaligarič and Poldini 1997, Dakskobler 1998, Dakskobler 2006). In $H$. pastinacifolia habitats at the southern edge of Trnovski gozd, grazing has resulted in semi-natural vegetation belonging to the alliance Satureion subspicatae, with many species characteristic for the subalpine alliance Seslerion albicantis (Kaligarič 1997). In rock crevices, $H$. pastinacifolia is found among other chasmophytic plants of the Potentilletalia caulescentis syntaxon (Kaligarič 1997, Dakskobler 1998). In the northern section, the area with open vegetation at the edge of the plateau is much narrower, ending abruptly towards the Trebuša valley. There, $H$. pastinacifolia is found growing only in patches of Caricetum firmae grasslands, which are more similar to plant communities from the southeastern Alps than from the northern Dinaric mountains (Surina and Dakskobler 2005).
According to its protected status and a recognized level of general concern, we have considerable knowledge of the species' life history, ecology and biology. Hladnikia pastinacifolia is a spring-germinating monocarpic species. The development of the flowering plant takes several vegetation seasons (Šajna et al. 2014). Before the flowering, plants form only basal rosettes of numerous glossy, leathery leaves. The white flowers are bisexual and protandrous. Frequent visits by insects and a high pollen-ovule ratio indicate cross-pollination by less successful pollinators (Šajna et al. 2014). The fruit is a typical schizocarp, at maturity splitting into two mericarps (hereafter, seeds) $4 \mathrm{~mm}$ long and $2 \mathrm{~mm}$ wide. On average, $60 \%$ of schizocarps are developed intact, and both mericarps are fertile (Šajna et al. 2014). Seed testa and fruit pericarp are connected, without any structures for better dispersal, whether by wind or animals. However, we still lack information about the germination strategy that has enabled the survival of $H$. pastinacifolia, and that should be of prime importance for understanding the rarity and persistence of any rare species.

Representatives of the Apiaceae family typically form seeds with abundant endosperm and an underdeveloped embryo (Martin 1946), which is true for H. pastinacifolia as well (Šajna et al. 2014). In such species, the fully developed seed cannot germinate until the embryo growth reaches the critical length needed for germination (Baskin and Baskin 2004). Seed morphology is often the cause behind a specific type of dormancy break. In various Apiaceae species from the temperate region, 4 types of dormancy have been observed (sensu Nikolaeva in Baskin and Baskin 1998): morphological dormancy - MD (Apium graveolens L., Conium maculatum L., Pastinaca sativa L.), non-deep simple morphophysiological dormancy - MPD (Selinum carviflora (L.) L., Angelica sylvestris L., Vandelook et al. 2007), nondeep complex MPD (Osmorhiza longistylis (Torr.) DC, Baskin and Baskin 1998), and deep complex MPD (Heracleum sphondylium L., Stokes 1952, Anthriscus sylvestris (L.) Hoffmann, Baskin et al. 2000, Aegopodium podagraria L., Phartyal et al. 2009). Dormancy type and germination can differ in seeds from a single individual if seed heteromorphism is present (Thomas et al. 1979, Baskin and Baskin 1998), especially if exhibited by morphological and anatomical differences between seeds from the main and lateral umbel in some Apiaceae (Thompson 1984, Moravcová et al. 2005, Jurkoniené et al. 2016). In H. pastinacifolia at first, only one main umbel (the first order umbel) is formed. Approximately one month later, when rosette leaves begin to senesce, the stem branches form several lateral umbels (the second order umbel). Therefore, different order umbels are visited by different pollinators (own observation) and we expected seeds from different umbels to differ in germination. This is especially likely because seed heteromorphism can be cryptic (Venable 1985) when seeds exhibit different germination behavior even though they are morphologically similar, e.g. they respond differently to cold stratification and water availability (Leverett and Jolls 2014).

We aimed to investigate the species' germination behavior, since $H$. pastinacifolia is extremely rare, geographically 
restricted, and at the same time believed to be one of the rare in situ survivors. Germination behavior is often in close relation to rarity, if germination rate is low. On the other hand, it can enable persistence, if dormant seeds are able to survive in the soil seed bank for long time. In this regard, germination behavior, together with seed dispersal potential and seedling establishment, is an important knowledge base for species conservation. We examined (1) embryo growth during after-ripening, (2) critical embryo length, (3) the germination rate in artificial and natural conditions, and (4) spatial distribution of seedlings in the natural habitat as an indication of dispersal.

\section{Materials and methods}

\section{Seed collection, embryo growth and germination}

Collection of ripe seeds was restricted in accordance with sampling permission from the Institute of the Republic of Slovenia for Nature Conservation. We were allowed to sample only a few plants and their parts in a natural $H$. pastinacifolia population at Predmeja (45 $56^{\circ} 33^{\prime \prime} \mathrm{N}, 13^{\circ} 52^{\prime} 50^{\prime \prime} \mathrm{E} ; 894 \mathrm{~m}$ a.s.l.). This population has been recognized as the one where sampling and other studies would have the least negative effect (Šajna et al. 2011). We collected randomly 40 seeds originating from the main and lateral umbels separately. At the beginning of November 2006 and September 2008, we buried seeds immediately after their collection on site and in 2008 we collected additional seeds at the same location for germination studies in the laboratory. After the end of the study, seedlings were used to start a tissue culture (Ambrožič Dolinšek et al. 2016, Ciringer et al. 2018) and the remaining seeds were returned to the natural site.

Seeds for the two laboratory tests were dry stored at room temperature until the beginning of the study in February 2009. We used only fully-developed seeds, as established by slightly pinching each one with forceps to see whether seeds contained a firm endosperm (Baskin and Baskin 1998).

In the first experiment the embryo length to seed length ratio, the $\mathrm{E}: \mathrm{S}$ ratio, was determined for imbibed seeds during after-ripening at $4{ }^{\circ} \mathrm{C}$ and $23{ }^{\circ} \mathrm{C}$ in the dark for seeds originating from two umbel orders by longitudinal hand-sections of 5 intact imbibed seeds each time (in total, 15 times in a 150 day period). Length was measured with an ocular micrometer. The critical embryo length and the critical E:S ratio were recorded at the time of seed coat rupture without radicle protrusion (Vandelook et al. 2007).

In each germination study of the second experiment, 20 unsterilized seeds were allowed to germinate on two layers of filter paper moistened with $10 \mathrm{~mL}$ deionized water in a petri dish $(\varnothing=10 \mathrm{~cm})$. We first tested under which conditions seeds germinate, and whether germination differed according to umbel origin. Therefore, both seed types were exposed to low temperature at $4{ }^{\circ} \mathrm{C}$ in the dark, or to 2 conditions in the growth chamber (photoperiod 12/8 h or total darkness, both at $23^{\circ} \mathrm{C}$ ). Seeds were either scarified (slight incision in the testa with a sterilized razor, not damaging the embryo) or left intact. The second part of the germination study was determination of the final maximal germination rate. We used the unscarified main and lateral umbel seeds from the study above, which were held at $4^{\circ} \mathrm{C}$ for 106 days (until May $15^{\text {th }}$ ), when we transferred them to the growth chamber.

To test how seeds respond to environmental conditions in the natural site, we performed a burial experiment in the field. In the autumn of 2006 and 2008, we buried nylon mesh bags containing 40 intact seeds, from the main and lateral umbel separately, $2 \mathrm{~cm}$ deep in the soil of Predmeja pasture. In 2006 we additionally put seeds under a large stone in a stone wall, and in 2008 we additionally buried seed in the roadside gravel at another location near Golobnica gorge (location details in Šajna et al. 2009). The bags that we had buried on $5^{\text {th }}$ of November 2006 were collected on $21^{\text {st }}$ of April 2007 , and the bags buried on $4^{\text {th }}$ of September 2008 were collected on $16^{\text {th }}$ of May 2009. Together with the seeds, we each time buried a temperature sensor (StowAway Tidbit XT; Onset Computer Corporation, Bourne, USA), which recorded values every 12 minutes. Temperature data was evaluated with BoxCar Pro 4 (Onset Computer Corporation, Bourne, USA) software.

\section{Seedling distribution in the microhabitat}

To test whether seed dispersal in a wet autumn is minimized by rain, which we expected would beat down the seeds on the site of the dead mother plant (Šajna et al. 2014), we evaluated seedling density and spatial occurrence at the microhabitat level. We selected four distinct habitats and/or localities where $H$. pastinacifolia was present. We did not include rock crevices, since the establishment of seedlings there is much more mediated by crevice density and availability than by dispersal itself. In the study habitats, plots (70 $\times 70 \mathrm{~cm}$ ) were installed, which were divided by a grid into 25 cells - subplots $(14 \times 14 \mathrm{~cm})$. We assessed seedling establishment at peak occurrence in June and August 2005 in Predmeja (2 permanent plots) and only in August on the gravel in Golobnica and on Poldanovec peak by counting the number of seedlings per subplot. For better understanding of the spatial distribution of $H$. pastinacifolia, we counted non-flowering rosettes and flowering plants on plots, as well.

Because fine-scale spatial environmental heterogeneity can influence plant establishment (Fenner and Thompson 2005), we measured the following microhabitat conditions in each subplot: soil temperature (once, in the middle of the subplot), soil depth (3 times per subplot), vegetation height and soil humidity (once in the middle of the subplot if substrate depth allowed). Connections between occurrences of $H$. pastinacifolia life stages and the measured plot characteristics were evaluated for significant correlations (at $\mathrm{p}<0.05$ ).

We expected that, in the event of low dispersal, seedlings would have a clustered distribution. Therefore, the density in a selected grid cell would correspond strongly to the density of a neighboring cell. For describing the spatial distribution of seedlings, we calculated whether the possibilities of seedling occurrence in a given subplot were higher if the num- 
bers of seedlings in the neighboring subplot were also high and vice versa. Therefore, we arranged the subplots according to seedling abundance and calculated for all 25 subplots the ratio in which their neighboring subplots contained 0,1 , $2,3, \ldots, n$ seedlings. For defining neighboring subplots, we applied the 8-cell neighbor rule (next-nearest neighbor), by which two subplots are considered neighbors if they share sides along either a cardinal or a diagonal direction.

\section{Results}

\section{Embryo growth}

Hladnikia pastinacifolia seeds have an underdeveloped embryo, which is of the linear axile type. Cotyledons are evident even though underdeveloped. At the time of dispersal, the embryo of $H$. pastinacifolia seeds measured about 0.4 $\mathrm{mm}$ and needed to reach the critical length for germination (Fig. 1).

Before we began to evaluate embryo growth in an imbibed seed, we measured the dry seeds as well, and this data is included in Fig. 2 as time zero. Un-imbibed seeds had, on average, an E:S ratio of $0.24 \pm 0.07$ (for the main umbel) and $0.20 \pm 0.03$ (seeds from the lateral umbel). Because of the seed's water uptake during imbibition, the E:S ratio decreased over the next few days. We noticed the first significant changes in embryo length only with seeds exposed to $4{ }^{\circ} \mathrm{C}$, where seeds from the lateral umbel already showed changes after 50 days, and seeds from the main umbel much later - after 92 days. However, we observed the first sporadic seedlings from

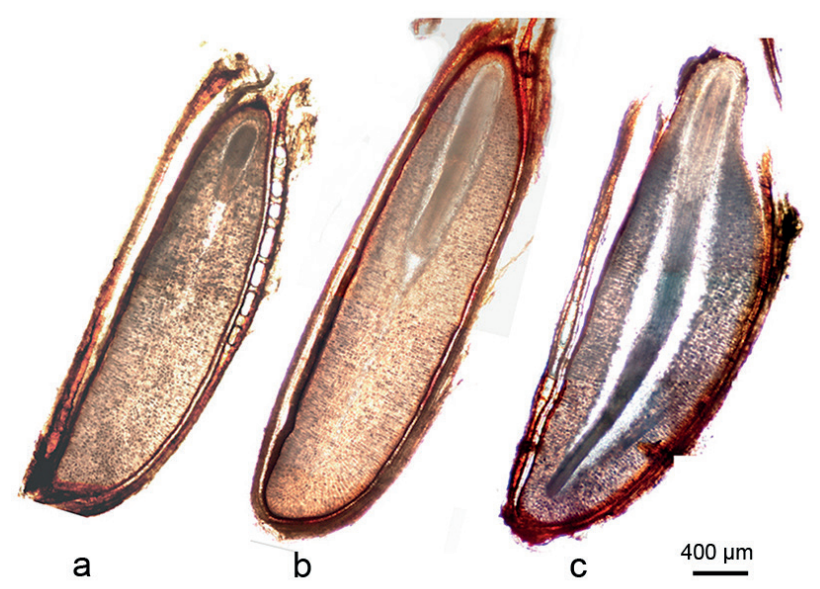

Fig. 1. Cross-sections of Hladnikia pastinacifolia seeds during germination: under-developed embryo (a), its elongation on the $90^{\text {th }}$ day (b), and embryo reaching the critical length inside the meri$\operatorname{carp}(\mathrm{c})$.

the main umbel emerge sooner than from the lateral umbel. Therefore, we estimated that 150 days at $4{ }^{\circ} \mathrm{C}$ is the maximum time when embryos in most mericarps reached their critical length above $3.6 \mathrm{~mm}$, whether originating from the main or the lateral umbel. We determined that the critical E:S ratio for the start of germination was above 0.84 .

\section{Germination in the laboratory}

To obtain representative germination results which we could later compare to the results from the natural site, we

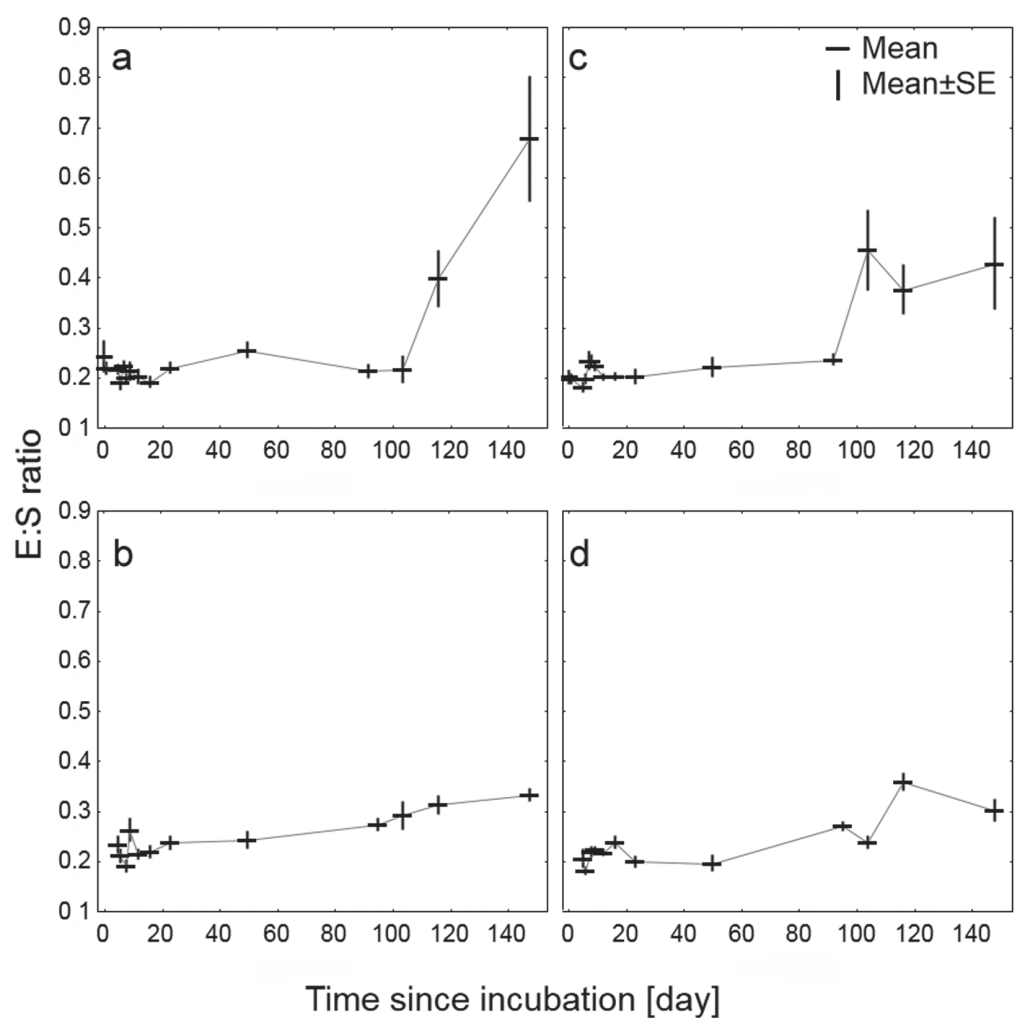

Fig. 2. Ratio between embryo length and seed length (E:S ratio) of Hladnikia pastinacifolia imbibed seeds during after-ripening at $4{ }^{\circ} \mathrm{C}$ and $23{ }^{\circ} \mathrm{C}$ : for mericarps of the lateral umbel at $4{ }^{\circ} \mathrm{C}(\mathrm{a})$, for mericarps of the lateral umbel at $23^{\circ} \mathrm{C}(\mathrm{b})$, for mericarps of the main umbel at $4{ }^{\circ} \mathrm{C}(\mathrm{c})$, for mericarps of the main umbel at $23^{\circ} \mathrm{C}(\mathrm{d})$. 
did not sterilize the seeds. In the growth chamber, all seeds from the main umbel were already overgrown by fungus (Fusarium sp.) after 4 days, and none germinated, while the first germinated seeds from the lateral umbel were observed after 102 days, with a germination rate (G\%) of $8 \%$. The first germinated seeds at $4{ }^{\circ} \mathrm{C}$ emerged after 92 days when originating from the main umbel and after 116 days in the case of lateral umbel seeds. After 116 days, we transported seeds originating from each umbel type from $4{ }^{\circ} \mathrm{C}$ to $23^{\circ} \mathrm{C}$. The final G\% after 175 days was $20 \%$ for seeds from the main umbel and $28 \%$ for seeds from the lateral umbel. Seeds from the main umbel reached a germination peak between the $144^{\text {th }}$ and $162^{\text {nd }}$ day (between $22^{\text {nd }}$ of June and $10^{\text {th }}$ of July), followed by seeds from the lateral umbel from day 160 onwards. Scarification increased the germination rate for the main umbel seeds to $92 \%$, and for lateral umbel seeds, to $76 \%$.

During further seedling development, the pericarp was first ruptured by the radicle, and at a radicle length of 0.9 $\mathrm{cm}$, the hypocotyl protruded from the pericarp (Fig. 3). At that time, the hypocotyl was bent like a hairpin (loop sensu Kondo et al. 2006). Cotyledons separated from the rest of the pericarp when the total seedling length measured between 1.6 and $2.5 \mathrm{~cm}$. The first leaf developed when the seedlings reached $4.5 \mathrm{~cm}$.

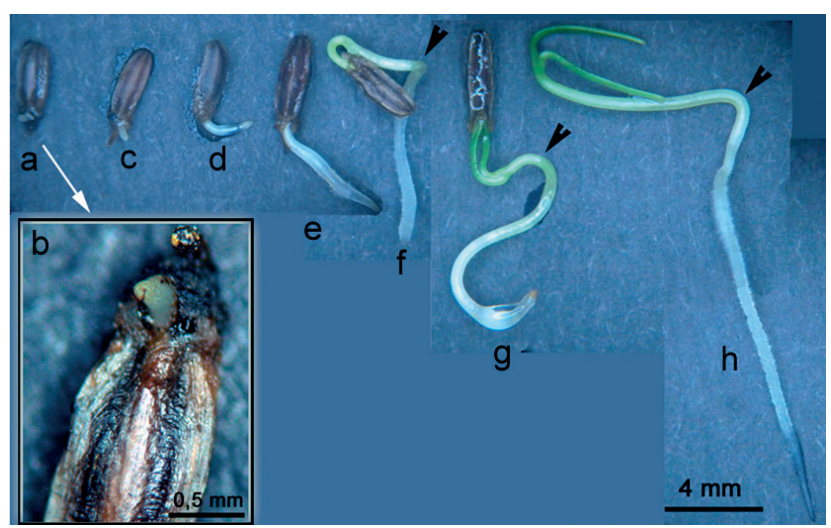

Fig. 3. Germination of Hladnikia pastinacifolia: radicle protruding (a), enlarged view (b), growth of the radicle (c) - (e), bent hypocotyl (black arrows indicating the loop) (f), cotyledons separated from the pericarp (h).

\section{Burial experiments}

In both burial experiments, the seeds were germinated at the time of excavation. Buried seeds were kept constantly in total darkness, especially in the case where the bag was placed under a stone. Seeds buried in November 2006 germinated best in the soil of the pasture - reaching a germination rate $(\mathrm{G} \%)$ of $38 \%$ for the main umbel and $30 \%$ for the lateral umbel seeds after 167 days, on $21^{\text {st }}$ of April. Seeds from bags placed in a man-made stone wall had lower G\%: main umbel seeds $30 \%$, lateral umbel seeds $8 \%$. We were able to transport these seeds into the laboratory, where the final G\% on $2^{\text {nd }}$ July, 2007 was as follows: $65 \%$ for main umbel seeds and $43 \%$ for lateral umbel seeds buried in pasture soil; $53 \%$ for main umbel seeds and 13\% for lateral umbel seeds buried in the stone wall.

Most of the seeds in bags buried in stony pasture soil for 253 days (from September 2008 until May 2009), germinated before their collection. However, the seedlings were still alive. The germination rate for main umbel seeds was $96 \%$, and $80 \%$ for lateral umbel seeds. On the other hand, all seedlings from seeds buried in the roadside gravel of the Golobnica gorge died of drought. Under the dissecting microscope, we were able to reconstruct $\mathrm{G} \%$ reached, which was $63 \%$ for the main umbel seeds and $20 \%$ for the lateral umbel seeds, while the un-germinated mericarps were full of Fusarium macroconidia.

The temperature conditions to which buried seeds were exposed (Fig. 4) in stony pasture on the southern part of the $\mathrm{H}$. pastinacifolia distribution (Predmeja) during winter 2006/07 showed a daily fluctuation of $7^{\circ} \mathrm{C}$ from September to November, and of about $9^{\circ} \mathrm{C}$ from mid-February onwards. Temperatures below $0^{\circ} \mathrm{C}$ prevailed for only one week at the end of December, reaching a minimum of $-1.4^{\circ} \mathrm{C}$ for one week in the beginning of February. Additionally, natural chilling conditions between 0 and $4{ }^{\circ} \mathrm{C}$ were first recorded on the $2^{\text {nd }}$ of November 2006, and finally on the $9^{\text {th }}$ of April 2007. During this 5-month period, chilling temperatures occurred on 91 days, with the longest series of 33 days in a row from the $9^{\text {th }}$ of December until the $10^{\text {th }}$ of January.

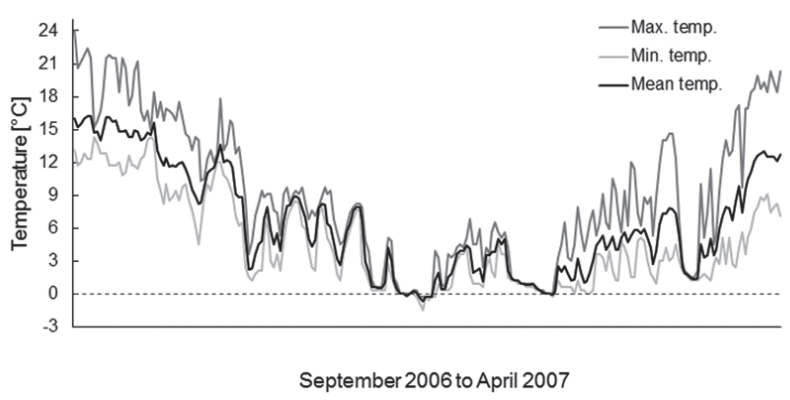

Fig. 4. Daily maximum, minimum and mean temperatures to which buried Hladnikia pastinacifolia seeds were exposed in natural habitat in Predmeja from September 2006 to April 2007.

\section{Distribution of various $H$. pastinacifolia developmental stages in relation to microhabitat characteristics}

Fine-scale spatial environmental heterogeneity of stony pasture habitat in June showed the following significant correlation with ontogenetic stage abundance: for seedlings, a negative correlation with soil humidity $(\mathrm{r}=-0.2957, \mathrm{p}=0.0371)$; for the cumulative number of $H$. pastinacifolia individuals, a negative correlation with soil humidity $(\mathrm{r}=-0.3043, \mathrm{p}=0.0317)$ and a positive one with soil depth $(r=0.2683, p=0.0596)$. Abundance was never significantly correlated with soil temperature in the pasture. For the man-made stone wall, we could only test for correlations with soil temperature, showing that the abundance of non-flowering rosettes was negatively correlated with soil temperature $(r=-0.1906, p=0.3614)$. 
When we evaluated the same plots in August, these correlations were consistent: a negative correlation between seedling abundance and soil humidity $(\mathrm{r}=-0.3282, \mathrm{p}=0.02)$ and a negative correlation between the cumulative number of $H$. pastinacifolia individuals and soil humidity $(\mathrm{r}=-0.3210, \mathrm{p}=$ 0.0230 ), since seedlings represent the majority of individuals. At the same time, the cumulative number of individuals as well as the number of non-flowering rosettes was positively related to soil depth in the pasture $(\mathrm{r}=0.0115, \mathrm{p}=0.937$ and $\mathrm{r}$ $=0.3503, \mathrm{p}=0.0126$, respectively). However, in August a significant correlation was found between seedling occurrence and temperature $(\mathrm{r}=0.3106, \mathrm{p}=0.0281)$.

The abundance of seedlings between June and August varied - decreasing or increasing by about $20 \%$, suggesting that seedling emergence occurred throughout the vegetation period. However, because of the contradictory effect of seedling emergence and mortality, we cannot use these results for seedling survival predictions.

In a similar habitat (stony grassland) on Poldanovec peak at the northern distribution margin, no correlations were found for either developmental stage. This was also true for the scree habitat in the Golobnica gorge.

\section{Spatial distribution of seedlings suggesting dispersal characteristics}

Spatial distribution of seedlings in various habitats (Fig. 5), calculated according to the possibility for seedling oc- currence in a given subplot and in the neighboring subplot, showed that in each habitat, a greater abundance of seedlings in a given subplot was more likely if the neighboring subplot contained more seedlings. All graphs showed an increase in seedling abundance more or less in the direction of the $\mathrm{x}=\mathrm{y}$ line.

\section{Discussion}

Consistently with other Apiaceae members, Hladnikia pastinacifolia forms seeds with underdeveloped embryos and abundant endosperm. The linear axile embryo is differentiated into cotyledons and a hypocotyl with radicle; however, the embryo is underdeveloped in terms of size at the time of dispersal. Seeds with such embryos exhibit dormancy related to the time required for the embryo to grow to the critical length when the radicle can protrude from the seed testa (Larcher 2003). If, additionally, specific temperature conditions for further embryo development are needed, germination is prevented by MPD (Baskin and Baskin 1998, Baskin and Baskin 2004, Vandelook et al. 2007). Both types, seeds from the main and from the lateral umbel, were morphologically dormant because of an underdeveloped embryo. According to germination results, the after-ripening during cold stratification at a constant temperature of $4{ }^{\circ} \mathrm{C}$ ended sooner in seeds from the main umbel and took 92 days, while germination from lateral seeds was observed 24 days later. In $H$. pastinacifolia, seeds of both types germinated immediately
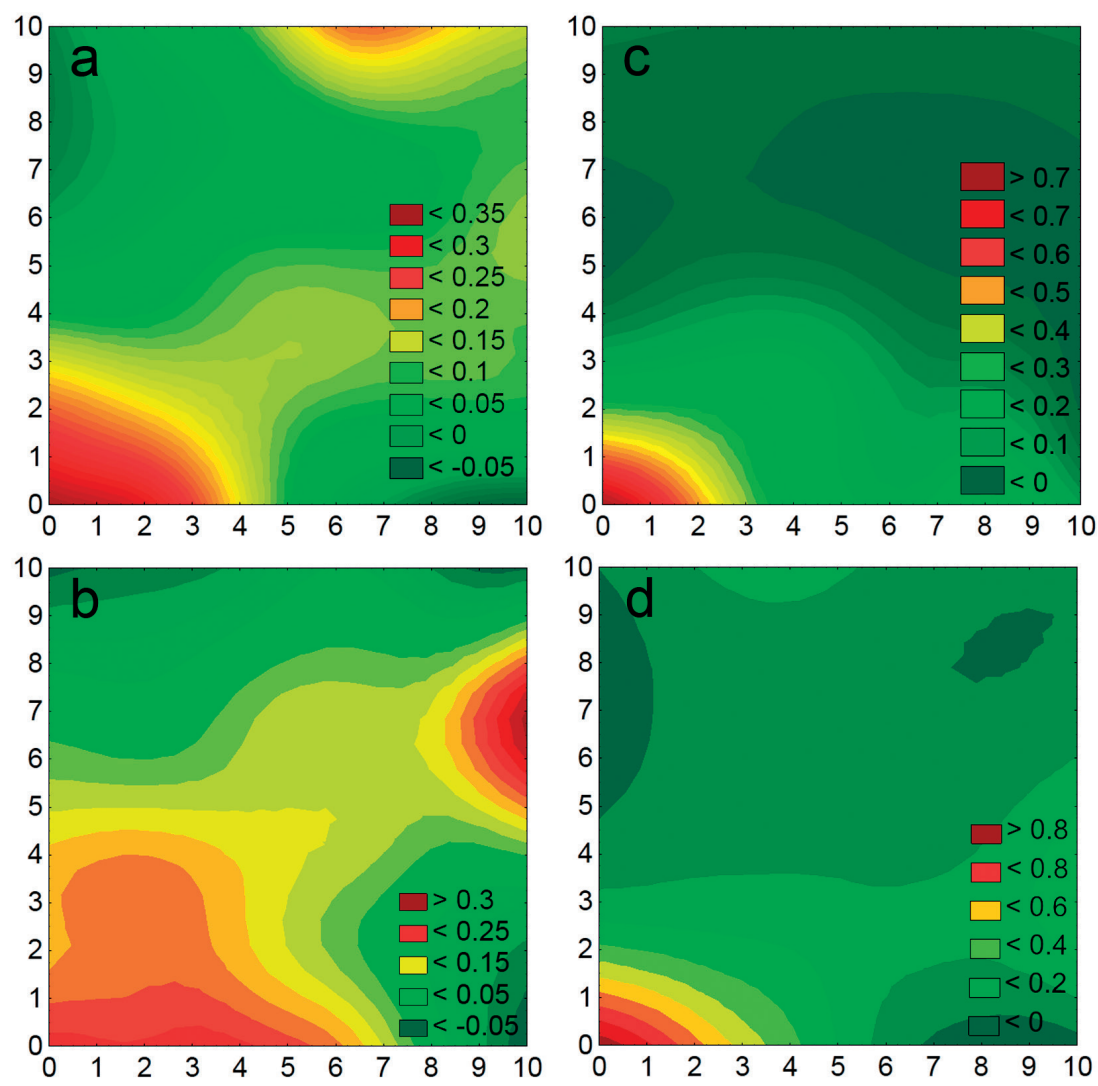

Fig. 5. Spatial distribution of Hladnikia pastinacifolia seedlings in a microhabitat: stony pasture (Predmeja) (a), man-made stone wall (Predmeja) (b), stony grassland (Poldanovec mountain peak) (c), gravel - scree (Golobnica gorge) (d). Colors show the proportion of seedlings present, where the data was optimized according to the distance weighted least squares method. For details see Materials and methods. 
after completion of embryo growth. The embryo in seeds from the main umbel grew only at low temperatures, indicating that the seeds have complex MPD. However, seeds from the lateral umbel also germinated in the growing chamber exposed to light, thus indicating simple MPD. As stressed by Baskin and Baskin (2004), to further evaluate which type of complex MPD (nondeep, intermediate, deep) is exhibited by seeds from the main umbel, we would have to test the response of the seeds to gibberellic acid $\left(\mathrm{GA}_{3}\right)$.

From laboratory studies, we have estimated that the ecologically relevant moist chilling period is about 100 days. The burial experiment enabled us to obtain the actual temperature sequence of the colder period which $H$. pastinacifolia seeds would receive in nature (averaged and pulled data from Fig. 4): $20 / 15^{\circ} \mathrm{C}$ (52 days), $10 / 5^{\circ} \mathrm{C}$ ( 40 days), $5 / 0^{\circ} \mathrm{C}$ ( 65 days), $10 / 0{ }^{\circ} \mathrm{C}$ (45 days), and finally $15 / 5^{\circ} \mathrm{C}$ (21 days). According to Phartyal et al. (2009), who studied the impact of temperature regimes on the germination of Aegopodium podagraria, the temperature of $0{ }^{\circ} \mathrm{C}$ was more favorable for the dormancy break than $5^{\circ} \mathrm{C}$. In nature, $H$. pastinacifolia seeds were cold stratified for 110 days at $0{ }^{\circ} \mathrm{C}$ (more precisely from -2.5 to $2.5^{\circ} \mathrm{C}$ ), a period of time similar to that needed in the laboratory studies conducted at $4{ }^{\circ} \mathrm{C}$. In the laboratory, G\% was increased by an additional $72 \%$ and $48 \%$, with scarification for seeds from the main and lateral umbel, respectively. In the natural scree habitat such scarification could easily happen when seeds fall into the gravel substrate. In the natural site, buried seeds' G\% for main umbel seeds was $96 \%$ and $80 \%$ for lateral umbel seeds, very similar to the G\% reached in the laboratory with scarification. In monocarpic species, plant establishment is critical for population persistence. They can recover population from a soil seed bank (e.g. Campanula cervicaria L., Often 1999, Eisto et al. 2000). Dormancy would assure that at least some seeds would germinate over a longer period; however, this was not the case in H. pastinacifolia. The high germination rate in natural conditions did not allow the establishment of a persistent soil seed bank, while at the same time, European Apiaceae generally have short-lived seeds (Walters et al. 2005).

Variability of fruits and seeds on a single plant can be a source of dispersal and of functional plasticity, increasing the recruitment potential of seedling establishment in space and time, especially under variable environmental conditions (Imbert 2002). Seed heteromorphism in H. pastinacifolia has to be understood as differences in germination characteristics related to the order of the umbel on which seeds occurred on the plant. This is a form of cryptic seed heteromorphism, shown in germination rate and dormancy type, but not exhibited by the seed size. True and cryptic heteromorphism is often associated with species growing in extreme, highly stressful, and/or unpredictable environments like deserts and fire-prone or open arid areas. However, heterodiaspory also occurs in weedy annuals of disturbed habitats even in temperate regions, as in the common Apiaceae member Apium gra- veolens (Gutterman 1992). Most habitats of $H$. pastinacifolia are sloped, while the most isolated population occupies a vertical rock outcrop. In all habitats, high environmental stress is present, combined with medium to strong disturbance. Such habitats, when they exhibit high irradiation and simultaneous gaps in vegetation cover, are characterized by the ability to host species with weak competitive potential because of slow succession (Černý et al. 2006). Similarly, the stenoendemic obligate chasmophyte Campanula tommasiniana (Surina 2013) is expected to have low biotic competitiveness, but this is in a way compensated with species' remarkable plasticity to tolerate various abiotic conditions (Surina and Martinčič 2014). The first indication that $H$. pastinacifolia has low competitive and low establishment potential in its habitats is the previously mentioned high germination rate of both seed types, which prevents seed accumulation in the soil seed bank to ensure persistence of the species over time. The second one is the strong correlation between seedling occurrence and soil humidity, especially since seedlings have a clustered distribution in space. High seedling density generally has a strong negative effect on seedling survival (Koelewijn 2004). Less clustered distribution of $H$. pastinacifolia seedlings was observed on the scree than in the pasture. This could be explained by the instability of the scree substrate rather than by seed dispersal. The scree habitat was also recognized as the most suitable habitat for $H$. pastinacifolia from morphological analyses (Šajna et al. 2012). According to the chasmophytes on screes in the close vicinity (Surina and Martinčič 2012), $H$. pastinacifolia could also be a niche edge left-over because of low dispersal. Adaptations for marginal persistence in the expected niche could be attributed to several traits involving drought tolerance (Šajna et al. 2014). Therefore, environmental constraints, including the presence of unoccupied gaps, are more crucial for the survival of relic species in such habitats than the species composition itself (Černý et al. 2006). We believe the same explanation can apply to $H$. pastinacifolia's occurrence and persistence in various plant communities, even though numerous attempts were made to describe typical $H$. pastinacifolia associations in the past. Open, unshady areas, like the karstic pasture in our study, seem to provide alternative open habitats.

\section{Acknowledgements}

The authors are grateful to $P$. Kušar for valuable commentary and to two anonymous reviewers for valuable suggestions improving the manuscript. We thank the Republic of Slovenia Institute of Nature Conservation for issuing the sampling permit. The study and publication was partly supported by the Slovenian Ministry of High Education, Science and Technology within the research programs P1-0078 and P1-0403. Nina Šajna acknowledges a grant from the Society for the Advancement of Plant Sciences in Vienna (Austria). 


\section{References}

Ambrožič Dolinšek, J., Ciringer, T., Kaligarič, M., 2016: Micropropagation of the narrow endemic Hladnikia pastinacifolia (Apiaceae). Acta Botanica Croatica 75, 244-252.

Baskin, C.C., Baskin, J.M., 1998: Seeds: ecology, biogeography and evolution of dormancy and germination. Academic Press, San Diego.

Baskin, J.M., Baskin, C.C., 2004: A classification system for seed dormancy. Seed Science Research 14, 1-16.

Baskin, C.C., Milberg, P., Anderson, L., Baskin, J.M., 2000: Deep complex morphophysiological dormancy in seeds of Anthriscus sylvestris (Apiaceae). Flora 195, 245-251.

Černý, T., Petř́ik, P., Boublík, K., Kolbek, J., 2006: Habitat requirements of Cardaminopsis petraea - rare and relict species of the Czech Republic. Biologia 61, 51-61.

Ciringer, T., Martín, C., Sajna, N., Kaligarič, M., Ambrožič-Dolinšek, J., 2018: Cryopreservation of an endangered Hladnikia pastinacifolia Rchb. by shoot tip encapsulation-dehydration and encapsulation-vitrification. In Vitro Cellular and Developmental Biology - Plant, 1-11.Čušin, B., 2004: Hladnikia pastinacifolia Rchb. In: Čušin, B. (ed.), Natura 2000 in Slovenia - Plants, 107-113. ZRC SAZU, Ljubljana (in Slovenian).

Dakskobler, I., 1998: Vegetation of forest reserve Govci in northeastern part of Trnovski gozd (eastern Slovenia). Proceedings 19 Forestry Days, Logarska dolina 269-301 (in Slovenian).

Dakskobler, I., 2006: Calcareous open sedge swards and stony grasslands (Seslerietalia caeruleae) on the northern edge of the Trnovski gozd plateau (the Dinaric Mountains, western Slovenia). Hacquetia 5, 73-112.

Eisto, A-K., Kuitunen, M., Lammi, A., Saari, V., Suhonen, J., Syrjäsuo, S., Tikka, P.M., 2000: Population persistence and offspring fitness in the rare bellflower Campanula cervicaria in relation to population size and habitat quality. Conservation Biology 14, 1413-1421.

Fenner, M., Thompson, K., 2005: The ecology of seeds. Cambridge University Press, Cambridge.

Grom, S., 1969: Moos flora of Trnovski gozd. Varstvo narave 6, 51-72 (in Slovenian).

Gutterman, Y., 2000: Maternal effects on seeds during development. In: Fenner, M. (ed.), Seeds: the ecology of regeneration in plant communities, 59-84. CABI Publishing, Wallingford.

Imbert, E., 2002: Ecological consequences and ontogeny of seed heteromorphism. Perspectives in Plant Ecology, Evolution and Systematics 5, 13-36.

Jurkonienè, S., Žalnierius, T., Gavelienė, V., Švegždienė, D., Šiliauskas, L., Skridlaitè, G., 2016. Morphological and anatomical comparison of mericarps from different types of umbels of Heracleum sosnowskyi. Botanica Lithuanica 22, 161-168.

Kaligarič, M., 1997: Flora of Primorska Karst and Slovenian Istria: grasslands and pastures ZRS Koper, Koper (in Slovenian).

Kaligarič, M., Poldini, L., 1997: Nuovi contributi per una tipologia fitosociologica delle Praterie magre (Scorzoneretalia villosae H-IĆ 1975) del Carso Nordadriatico = New contributions on the typology of the vegetation of dry grasslands (Scorzoneretalia villosae H-IĆ 1975) in the North Adriatic Karst. Gortania 19, 119-148.

Koelewijn, H.P., 2004: Sibling competition, size variation and frequency-dependent outcrossing advantage in Plantago coronopus. Evolutionary Ecology 18, 51-74.

Kondo, T., Sato, C., Baskin, J.M., Baskin, C.C., 2006: Post-dispersal embryo development, germination phenology, and seed dormancy in Cardiocrinum cordatum var. glehnii (Liliaceae s. str.), a perennial herb of the broadleaved deciduous forest in Japan. American Journal of Botany 93, 849-859.
Kranjc, A., 2006: Some large dolines in the Dinaric karst. Speleogenesis and Evolution of Karst Aquifers 4, 1-4.

Larcher, W., 2003: Physiological plant ecology: ecophysiology and stress physiology of functional groups. Springer, Berlin.

Leverett, L.D., Jolls, C.L., 2014: Cryptic seed heteromorphism in Packera tomentosa (Asteraceae): differences in mass and germination. Plant Species Biology 29, 169-80.

Martin, A.C., 1946: The comparative internal morphology of seeds. The American Midland Naturalist 36, 513-660.

Martinčič, A., 1961: Contributions to knowledge about flora of Slovenian territory. Biološki Vestnik 8, 3-8 (in Slovenian).

Mayer, E., 1960: Endemic Phanerogams from the South-Eastern calcareous Alps, their foothills and Illirian transition area. In: Lazar, J. (ed.), Zbornik ob 150. letnici botaničnega vrta v Ljubljani, 26-45. SAZU, Ljubljana. (in Slovenian)

Melik, A., 1960: Slovenia - Slovenian Coastal Region 2(4). Slovenska matica, Ljubljana. (in Slovenian)

Moravcová, 1., Perglová, I., Pyšek, P., Jarosik, V., Pergl, J., 2005: Effects of fruit position on fruit mass and seed germination in the alien species Heracleum mantegazzianum (Apiaceae) and the implications for its invasion. Acta Oecologica 28, 1-10.

Often, A., 1999: Campanula cervicaria: Seed arresting mechanism and seed pools in winter stander and soil. Flora 194, 103-112.

Orehek, S., Ogorelec, B., 1979: Sedimentologic features of the Jurassic and Cretaceous carbonate rocks of Trnovski gozd. Geološki vestnik 32, 185-192 (in Slovenian).

Pawlowski, B., 1970: Remarques sur l'endemisme dans la flore des Alpes et des Carpates. Vegetatio 21, 181-243.

Perko, D., 2001: Analysis of the surface of Slovenia using the 100$\mathrm{m}$ digital elevation model. ZRC SAZU, Ljubljana. (in Slovenian).

Phartyal, S.S., Kondo, T., Baskin, J.M., Baskin, C.C., 2009: Temperature requirements differ for the two stages of seed dormancy break in Aegopodium podagraria (Apiaceae), a species with deep complex morphophysiological dormancy. American Journal of Botany 96, 1086-1095.

Poldini, L., 1978: La vegetazione petrofila dei territori carsici nordadriatici. Poročila Vzhodnoalpsko-dinarskega društva za proučevanje vegetacije 14, 297-324.

Pristov, J., 1997: The climate of the Trnovsko-Banjška planota. Acta Carsologica 26, 30-38.

Šajna, N., Kušar, P., Slana Novak, L., Novak, T., 2009: Notes on thermo- and hygropreference in Leiobunum roseum C.L. Koch, 1839 (Opiliones: Sclerosomatidae) in a habitat of Hladnikia pastinacifolia Reichenbach, 1831 (Spermatophyta: Apiaceae). Contributions to natural history (Bern) 12, 11111123.

Šajna, N., Kušar, P., Slana Novak, L., Novak, T., 2011: Benefits of low-intensive grazing: co-occurrence of umbelliferous plant (Hladnikia pastinacifolia Rchb.) and opilionid species (Phalangium opilio L.) in dry, calcareous grassland. Polish Journal of Ecology 59, 777-786.

Šajna, N., Kavar, T., Šuštar Vozlič, J., Kaligarič, M., 2012: Population genetics of the narrow endemic Hladnikia pastinacifolia Rchb. (Apiaceae) indicates survival in situ during the Pleistocene. Acta Biologica Cracoviensia. Series Botanica 54, 84-96.

Šajna, N., Šuštar Vozlič, J., Kaligarič, M., 2014: New insights into the anatomy of an endemic Hladnikia pastinacifolia Rchb. Acta Botanica Croatica 73, 375-384.

Schneeweiss, G.M., Schönswetter, P., 2011: A re-appraisal of nunatak survival in arctic-alpine phylogeography. Molecular Ecology 12, 190-192.

Stokes, P., 1952: A physiological study of embryo development in Heracleum sphondylium L. I. The effect of temperature on embryo development. Annals of Botany 16, 441-447. 
Surina, B., 2013: Discovery, updated distribution area and habitat preferences of Campanula tommasiniana, a narrow endemic of Mt Ucka (Liburnian karst, north-western Adriatic). Natura Croatica 22, 171-180.

Surina, B., Dakskobler, I., 2005: Delimitation of the alliances Caricion firmae (Seslerietalia albicantis) and Seslerion juncifoliae (Seslarietalia juncifoliae) in the southeastern Alps and Dinaric mountains. Plant Biosystems 139, 399-410.

Surina, B., Martinčič, A., 2012: Chasmopyhtes on screes? A rule and not an exception in the vegetation of the Karst (southwest Slovenia). Plant Biosystems 146, 1078-1091.

Surina, B., Martinčič, A. 2014: Ecology and niche assembly of Campanula tommasiniana, a narrow endemic of Mt Učka (Liburnian karst, north-western Adriatic). Acta Botanica Croatica $73,221-254$

Thomas, T.H., Biddington, N.L., O’Toole, D.F., 1979: Relationship between position on the parent plant and dormancy characteristics of seeds of three cultivars of Celery (Apium graveolens). Physiologia Plantarum 45, 492-496.
Thompson, J.N., 1984: Variation among individual seed masses of Lomatium grayi (Umbelliferae) under controlled conditions: magnitude and partitioning of the variance. Ecology 65, 626-631.

Vandelook, F., Bolle, N., Van Assche, J.A., 2007: Multiple environmental signals required for embryo growth and germination of seeds of Selinum carvifolia L.) L. and Angelica sylvestris L. (Apiaceae). Seed Science Research 17, 283-291.

Venable, D.L., 1985: The evolutionary ecology of seed heteromorphism. The American Naturalist 126, 577-595.

Walters, C., Wheeler, L.M., Grotenhuis, J.M., 2005: Longevity of seeds stored in a genebank: species characteristics. Seed Science Research 15, 1-20.

Westergaard, K.B., Alsos, I.G., Popp, M., Engelskjøn, T., Flatberg, K.I., Brochmann, C., 2011: Glacial survival may matter after all: nunatak signatures in the rare European populations of two west-arctic species. Molecular Ecology 20, 376-393.

Wraber, T., 1990: Čaven, ein botanisch beruhmter Berg in Slowenien. Carinthia 180, 195-210. 